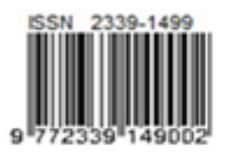

\title{
Pemeliharaan Mesin Hydraulic Shear Menggunakan Pendekatan Reliability Centered Maintenance dan Manajemen Suku Cadang
}

\author{
Faisal Mustaqim ${ }^{1}$, Wilson Kosasih ${ }^{2}$, Ahmad $^{3}$ \\ 1,2,3) Program Studi Teknik Industri, Fakultas Teknik, Universitas Tarumanagara \\ Jl. Let. Jend S. Parman No.1 Jakarta 11440 \\ E-mail: faisalmustaqim96@gmail.com, wilsonk@ft.untar.ac.id, ahmad@ft.untar.ac.id
}

\begin{abstract}
Production equipment that has a high operating time becomes a vital aspect in supporting the operational system, and its maintenance becomes a critical point that must be planned. This research discusses maintenance policies that focus on machine reliability and parts availability to produce proper maintenance actions, optimal maintenance scheduling and good spare-parts management. The research was conducted on a developing manufacturing company engaged the field of agricultural aids in the city of Bekasi. This study focused on hydraulic shear machines because they have the largest downtime value of 8,344.8 minutes. This problem has a negative impact on the company because it can reduce the yield. Based on these conditions, the study was conducted using the Reliability Centered Maintenance method to update the maintenance patterns and Poisson Process to determine the number of component requirements needed for the next one year. The data obtained in the form of historical damage to the machine, component cost, labor cost and production cost. This research produces an optimal preventive replacement time interval that is every 154 hours for the oil seal component, 242 hours for the shear blade component, and 324 hours for the oil hydraulic hose (1/2") component. While the number of critical components required for the next 1 year is 37 units for oil seal component, 10 units for shear blade components, and 7 units for oil hydraulic hose (1/2") component.
\end{abstract}

Keywords: maintenance, reliability centered maintenance, spare parts management

\begin{abstract}
Abstrak
Peralatan produksi yang memiliki waktu operasi tinggi menjadi aspek vital dalam mendukung sistem operasional, dan pemeliharaannya menjadi poin kritis yang harus direncanakan. Penelitian ini membahas kebijakan pemeliharaan yang berfokus pada keandalan mesin dan ketersediaan suku cadang untuk menghasilkan tindakan pemeliharaan yang tepat, penjadwalan pemeliharaan optimal dan manajemen suku cadang yang baik. Penelitian dilakukan pada perusahaan manufaktur berkembang yang bergerak pada bidang alat bantu pertanian di Kota Bekasi. Studi ini berfokus pada mesin hydraulic shear karena memiliki nilai downtime terbesar yakni 8.344,8 menit. Permasalahan ini berdampak buruk terhadap perusahaan karena dapat menurunkan rendemen. Berdasarkan kondisi tersebut, penelitian dilakukan dengan menggunakan metode Reliability Centered Maintenance untuk memperbaharui pola pemeliharaan dan Poisson Process untuk mengetahui jumlah kebutuhan komponen yang diperlukan selama satu tahun ke depan. Data yang diperoleh berupa historis kerusakan mesin, biaya komponen, biaya tenaga kerja dan biaya produksi. Penelitian ini menghasilkan interval waktu penggantian pencegahan optimal yakni setiap 154 jam untuk komponen oil seal, 242 jam untuk komponen shear blade, dan 324 jam untuk komponen oil hydraulic hose (1/2"). Sedangkan jumlah kebutuhan komponen kritis selama 1 tahun ke depan yakni 37 unit untuk komponen oil seal, 10 unit untuk komponen shear blade, dan 7 unit untuk komponen oil hydraulic hose (1/2").
\end{abstract}

Kata kunci: pemeliharaan, reliability centered maintenance, manajemen suku cadang 


\section{Pendahuluan}

Pemeliharaan mesin sangat diperlukan dalam sebuah industri terutama di bidang manufaktur yang memiliki peran penting selama proses produksi berlangsung. Buruknya penjadwalan pemeliharaan menjadi salah satu faktor yang mengakibatkan terjadinya breakdown secara tiba-tiba (Ahyari, 2002). Kegiatan pemeliharaan fasilitas pabrik sangat dibutuhkan agar aktivitas produksi berjalan sesuai dengan schedule yang telah dibuat (Assauri, 1993). Pemeliharaan merupakan kombinasi dari berbagai tindakan yang dilakukan untuk menjaga suatu komponen atau mesin dalam atau memperbaikinya sampai suatu kondisi dapat diterima (Kurniawan, 2013). Kegiatan pemeliharaan yang baik dilakukan sesuai dengan schedule yang telah ditetapkan tanpa mengganggu jalannya proses produksi. Jika kegiatan pemeliharaan sering dilakukan akan meningkatkan biaya pemeliharaan, sebaliknya apabila pemeliharaan jarang atau sama sekali tidak dilakukan akan mengurangi keandalan pada sebuah mesin (Corder, 1997; Dhillon, 2002; Kosasih et al., 2014).

Kegiatan pemeliharaan dapat meminimasi kerugian yang ditimbulkan akibat terjadinya kegagalan pada mesin dan meningkatkan rendemen yang didapat oleh perusahaan. Pemeliharaan bertujuan mempertahankan dan menjaga suatu sistem atau fasilitas tetap berada dalam kondisi aman, ekonomis dan pengoperasian optimal (Kurniawan, 2013). Selain itu manajemen suku cadang sangat diperlukan, dikarenakan harus memiliki pengendalian tingkat persediaan, sehingga ketika sebuah suku cadang diperlukan maka selalu tersedia dan menjaga agar tingkat persediaan berada pada level seminimum mungkin (Indrajit \& Djokopranoto, 2003).

Penelitian ini dilakukan pada perusahaan manufaktur berkembang yang bergerak pada bidang alat bantu pertanian di Kota Bekasi. Dalam kasusnya, perusahaan masih menerapkan run to failure maintenance pada sistem pemeliharaannya, di mana aksi dilakukan setelah mesin atau fasilitas produksi mengalami kegagalan atau kerusakan sehingga tidak dapat berfungsi dengan baik (Moubray, 2000). Pemeliharaan mesin bukan hanya tindakan corrective, tetapi terdapat tindakan preventive untuk mencapai keseimbangan antara keahlian sumber daya manusia dengan kebutuhan stakeholders (Kennedy, 2009; Ahmad et al., 2014). Kondisi tersebut berpotensi mempengaruhi produktivitas mesin, karena akan mengalami breakdown secara tiba-tiba dan menurunkan jumlah rendemen yang akan didapat oleh perusahaan.

Berdasarkan masalah tersebut, maka dilakukan penelitian ini mengenai pemeliharaan mesin hydraulic shear menggunakan pendekatan reliability centered maintenance dan manajemen suku cadang. Reliability centered maintenance merupakan landasan dasar untuk pemeliharaan fisik dan suatu teknik yang dipakai untuk mengembangkan pemeliharaan pencegahan (preventive maintenance) yang terjadwal (Siddiqui \& Ben, 2009). Dengan pendekatan tersebut diharapkan dapat memperbaharui pola pemeliharaan dan perencanaan jadwal pemeliharaan yang tepat pada komponen kritis serta mengetahui jumlah kebutuhan masingmasing komponen kritis pada mesin hydraulic shear sehingga tidak terjadi stockout.

\section{Metodologi}

Pada tahap awal, studi lapangan dilakukan pada penelitian ini untuk mengidentifikasi permasalahan di perusahaan dan selanjutnya dilakukan studi literatur mengenai metode yang akan digunakan. Ketika metode sudah ditentukan, langkah berikutnya pengumpulan data berupa historis kerusakan mesin mulai dari bulan Februari 2018 hingga Januari 2020. Data tersebut akan dilakukan analisa menggunakan failure mode and effect analysis (FMEA) untuk menentukan komponen kritis yang akan menjadi objek penelitian. Tools ini menggambarkan tingkat kejadian kerusakan (occurance - O), tingkat keparahan (severity S) dan tingkat deteksi kerusakan (detection D) yang dinyatakan dengan risk priority number (RPN) (Stamatis, 1995).

Selanjutnya dilakukan perhitungan TTF dan TTR. Hasil dari perhitungan tersebut dilakukan uji goodness of fit dengan menggunakan statistics software untuk mengetahui jenis distribusi kerusakan pada masing-masing komponen kritis. Distribusi terpilih menentukan formula yang akan digunakan dalam menghitung parameter guna mendapatkan nilai MTTF dan MTTR komponen serta reliability komponen (Ebeling, 1997). Pemilihan 
distribusi berdasarkan nilai anderson darling terkecil dan $p$-value terbesar (Anderson \& Darling, 1954). Setelah nilai MTTF dan MTTR diketahui, step berikutnya melakukan perhitungan interval penggantian pencegahan dan pemeriksaan pencegahan komponen kritis. Digunakan metode age replacement dalam menghitung interval penggantian pencegahan.

Kemudian melakukan perhitungan perbandingan reliability sebelum dan sesudah melakukan preventive maintenance agar mengetahui apakah reliability meningkat atau tidak. Reliability didefinisikan sebagai probabilitas bahwa suatu komponen atau sistem akan beroperasi sesuai dengan fungsi yang diperlukan untuk periode waktu tertentu ketika digunakan di bawah kondisi operasi yang ditetapkan (Ebeling, 1997). Selain itu juga dilakukan perhitungan perbandingan biaya dengan menerapkan preventive maintenance dan tanpa menerapkan preventive maintenance.

Langkah terakhir dihitung kebutuhan persediaan suku cadang tiap komponen kritis menggunakan pendekatan metode Poisson process dan model economic order quantity (EOQ).

\section{Hasil dan Diskusi}

\section{Penentuan Mesin dan Komponen Kritis}

Penentuan mesin kritis untuk menunjang penelitian, dikumpulkan historis kerusakan mesin pada area construction, seperti terlihat pada Gambar 1. Kemudian dipilih mesin yang memiliki frekuensi kerusakan tertinggi untuk menjadi objek penelitian.

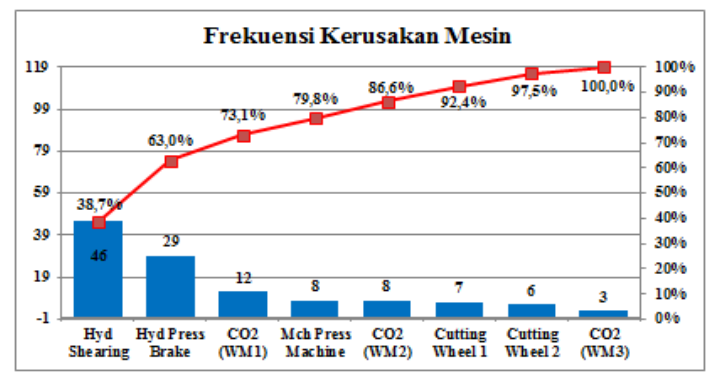

Gambar 1. Data kerusakan mesin

Mesin dengan frekuensi tertinggi terdapat pada mesin hydraulic shear yang merupakan mesin dengan frekuensi tertinggi diantara mesin-mesin lainnya dengan frekuensi kerusakan sebanyak 46 kerusakan. Maka dari itu mesin hydraulic shear menjadi objek penelitian. Berdasarkan historis kerusakan pada mesin hydraulic shear, terdapat 7 komponen yang tercatat kerusakannya. Komponen tersebut akan dianalisis menggunakan failure mode and effect analysis (FMEA) seperti ditunjukkan pada Tabel 1. Penentuan S-O-D dalam FMEA dilakukan berdasarkan konsensus dengan pihak manajemen. Adapun kriteria penilaiannya mengacu pada skala rating 10 poin dari FMEA (lihat Lampiran).

Tabel 1. Hasil failure mode and effect analysis

\begin{tabular}{|c|c|c|c|c|}
\hline Component & Severity & Occurance & Detection & RPN \\
\hline $\begin{array}{c}\text { Motor of } \\
\text { Back Gauge }\end{array}$ & 6 & 3 & 6 & 108 \\
\hline Shear Blade & 7 & 7 & 7 & 343 \\
\hline Oil Seal & 7 & 8 & 8 & 448 \\
\hline Footswitch & 6 & 2 & 3 & 36 \\
\hline Ball Screw & 6 & 4 & 6 & 144 \\
\hline Oil Hydraulic Hose & 8 & 7 & 8 & 448 \\
\hline Timing Belt & 5 & 4 & 5 & 100 \\
\hline
\end{tabular}

Selain FMEA, digunakan diagram Pareto dengan prinsip $80 / 20$ sebagai penguat dalam menentukan objek penelitian. Gambar 2 menunjukkan hasil pareto dari tiap komponen mesin hydraulic shear.

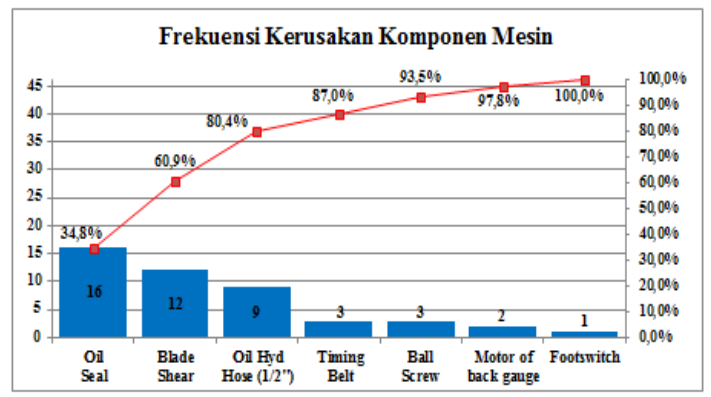

Gambar 2. Data kerusakan komponen mesin hydraulic shear

Berdasarkan hasil FMEA, terlihat komponen oil seal, shear blade dan oil hydraulic hose (1/2") memiliki nilai RPN tinggi dan terpilih menjadi objek penelitian. Hasil failure mode and effect analysis diperkuat dengan hasil pareto, karena ketiga komponen memiliki persentase kumulatif mencapai $80 \%$.

\section{Perhitungan Parameter, MTTF dan MTTR}

Penentuan distribusi TTF dan TTR pada masing-masing komponen kritis dilakukan dengan pengujian goodness of fit menggunakan bantuan statistics software. Distribusi ini menghasilkan parameter dari tiap 
TTF dan TTR pada ketiga komponen kritis. Hasil pengujian distribusi beserta hasil parameter dapat dilihat pada Tabel 2 .

Hasil uji goodness of fit menunjukkan distribusi terpilih dari setiap komponen kritis. Tahap selanjutnya menghitung waktu rata-rata menuju kerusakan dan waktu ratarata proses perbaikan terhadap ketiga komponen kritis. Perhitungan disesuaikan dengan distribusi terpilih pada tiap komponen kritis, karena tiap distribusi memiliki formula yang berbeda-beda. Tabel 3 menunjukkan hasil perhitungan MTTF dan MTTR dari ketiga komponen kritis.

Tabel 2. Hasil uji distribusi \& parameter

\begin{tabular}{|c|c|c|}
\hline Component & Distribusi & Parameter \\
\hline \multirow{4}{*}{ Oil Seal } & \multirow{2}{*}{\begin{tabular}{c|} 
TTF \\
Lognormal
\end{tabular}} & $s: 0,6140$ \\
\hline & & $t_{\text {med }}: 238,4105$ \\
\hline & \multirow{2}{*}{\begin{tabular}{c|} 
TTR \\
Lognormal
\end{tabular}} & $s: 0,1014$ \\
\hline & & $t_{\text {med }}: 3,3275$ \\
\hline \multirow{4}{*}{ Shear Blade } & \multirow{2}{*}{$\begin{array}{c}\text { TTF } \\
\text { Lognormal } \\
\end{array}$} & $s: 0,2869$ \\
\hline & & $t_{\text {med }}: 343,6980$ \\
\hline & \multirow{2}{*}{ TTR Normal } & $\sigma: 0,6559$ \\
\hline & & $\mu: 5,9029$ \\
\hline \multirow{4}{*}{$\begin{array}{c}\text { Oil Hydraulic } \\
\text { Hose }(1 / 2 ")\end{array}$} & \multirow{2}{*}{ TTF Normal } & $\sigma: 152,4157$ \\
\hline & & $\mu: 500,8687$ \\
\hline & \multirow{2}{*}{$\begin{array}{c}\text { TTR } \\
\text { Lognormal }\end{array}$} & $s: 0,3899$ \\
\hline & & $t_{\text {med }}: 1,5148$ \\
\hline
\end{tabular}

Tabel 3. Hasil perhitungan MTTF dan MTTR komponen kritis

\begin{tabular}{|c|c|c|}
\hline Component & MTTF (Jam) & MTTR (Jam) \\
\hline Oil Seal & 287,8650 & 3,3446 \\
\hline Shear Blade & 358,1382 & 5,9029 \\
\hline $\begin{array}{c}\text { Oil Hydraulic } \\
\text { Hose }\end{array}$ & 500,8687 & 1,6344 \\
\hline
\end{tabular}

\section{Penentuan Interval Waktu Penggantian dan Pemeriksaan Pencegahan}

Pemeliharaan mesin sebaiknya dilaksanakan secara terjadwal dan bersifat direncanakan. Tindakan tersebut dapat meminimalisir terjadinya breakdown pada mesin secara tiba-tiba yang akan menghambat kelancaran proses produksi. Tindakan penggantian pencegahan pada tiap komponen kritis dengan tingkat frekuensi kegagalan tinggi dapat mempengaruhi proses kerja sistem secara keseluruhan. Sedangkan tindakan pemeriksaan pencegahan bertujuan untuk meminimasi downtime mesin akibat kerusakan yang terjadi secara tiba-tiba (Jardine, 1993).

Dengan dilakukannya perhitungan interval waktu penggantian dan pemeriksaan pencegahan, didapat waktu optimal dalam melakukan tindakan penggantian dan pemeriksaan terhadap ketiga komponen kritis. Tabel 4 menunjukkan hasil perhitungan interval waktu penggantian dan pemeriksaan pencegahan.

Hasil perhitungan interval waktu penggantian pencegahan menunjukkan bahwa penggantian komponen dilakukan setelah pemakaian 154 jam untuk komponen oil seal, 242 jam untuk komponen shear blade dan 324 jam untuk komponen oil hydraulic hose (1/2"). Sedangkan Hasil perhitungan interval waktu pemeriksaan pencegahan menunjukkan pemeriksaan komponen dilakukan setelah pemakaian 65 jam untuk komponen oil seal, 70 jam untuk komponen shear blade dan 124 jam untuk komponen oil hydraulic hose (1/2").

Tabel 4. Interval waktu penggantian dan pemeriksaan pencegahan

\begin{tabular}{|c|c|c|}
\hline Component & $\begin{array}{c}\text { Interval Waktu } \\
\text { Penggantian }\end{array}$ & $\begin{array}{c}\text { Interval Waktu } \\
\text { Pemeriksaan }\end{array}$ \\
\hline Oil Seal & 154 Jam & 65 Jam \\
\hline Shear Blade & 242 Jam & 70 Jam \\
\hline Oil Hydraulic Hose & 324 Jam & 124 Jam \\
\hline
\end{tabular}

\section{Perbandingan Reliability Sebelum dan}

\section{Sesudah Preventive Maintenance}

Keandalan sebuah komponen berhubungan apakah komponen tersebut dapat beroperasi dengan baik tanpa mengalami kerusakan atau tidak. Peningkatan keandalan dapat dilakukan dengan cara pemeliharaan pencegahan, karena mampu meningkatkan umur pakai sebuah komponen

Perhitungan reliability pada ketiga komponen kritis disesuaikan dengan distribusi terpilih berdasarkan hasil uji goodness of fit. Hasil perhitungan perbandingan reliability komponen kritis dapat dilihat masing-masing pada Gambar 3, Gambar 4, Gambar 5.

\section{RCM Worksheet}

Pada pendekatan ini digunakan RCM information worksheet dan decision worksheet. RCM information worksheet merupakan lembaran kerja yang merangkum informasi mengenai kegagalan yang terjadi pada komponen kritis. RCM information worksheet mengenai komponen kritis dapat dilihat pada Tabel 5, Tabel 6, Tabel 7. 


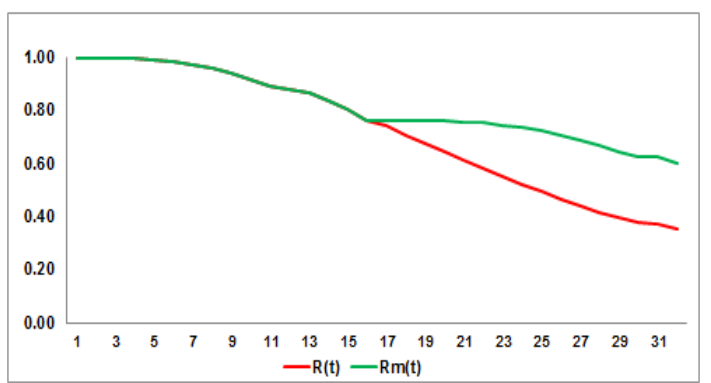

Gambar 3. Perbandingan reliability oil seal

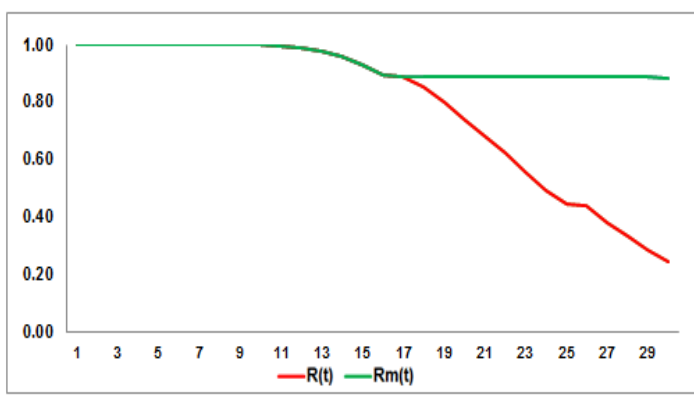

Gambar 4. Perbandingan reliability shear blade

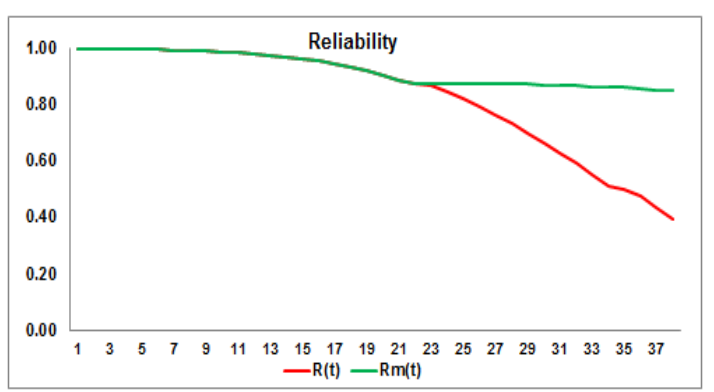

Gambar 5. Perbandingan reliability oil hydraulic hose (1/2")

Tahap selanjutnya menentukan dampak atau konsekuensinya yang ditimbulkan oleh kegagalan serta tindakan proactive maintenance untuk menghadapi kegagalan yang terjadi dengan membuat RCM decision worksheet. Hasil RCM decision worksheet komponen kritis dapat dilihat pada Tabel 8. Nilai 1 pada kolom function karena hanya terdapat 1 fungsi yang mengalami kegagalan, Nilai A pada kolom function failure karena pola kerusakan komponen bersifat dimulai frekuensi kegagalan yang tinggi diikuti dengan keadaan konstan dan berakhir dengan wear out dan Niai 1 pada kolom failure mode menyatakan modus kegagalan yang terjadi berjumlah 1 . Sedangkan N memiliki arti "tidak" dan $Y$ memiliki arti "ya". Pada proses penentuan consequence evaluation serta tindakan pencegahan (proactive task) dibantu dengan menggunakan diagram keputusan RCM (decision diagram). Kegiatan preventive task pada ketiga komponen kritis terpilih yaitu schedule discard task, di mana pada task ini melakukan penggantian komponen lama dengan komponen baru pada atau sebelum batas umur pakai sehingga dapat mengembalikan ketahanan komponen terhadap failure. Default action tidak diisi karena preventive task sudah memungkinkan diimplementasikan.

\section{Perbandingan Failure Cost Dan Preventive Cost}

Perhitungan biaya pemeliharaan digunakan untuk mengetahui perbedaan antara sebelum melakukan preventive maintenance dan sesudah melakukan preventive maintenance. Tabel 9 menunjukkan hasil saving cost pada ketiga objek penelitian.

Hasil perhitungan menunjukkan pada saat menerapkan preventive maintenance dapat menghemat biaya pemeliharaan sebesar $79,65 \%$ untuk komponen oil seal, $79,46 \%$ untuk komponen shear blade dan $84,78 \%$ untuk komponen oil hydraulic hose (1/2").

\section{Perencanaan Persediaan Suku Cadang Komponen Kritis}

Tiap komponen dibedakan menjadi repairable dan non-repairable. Seluruh komponen kritis tergolong dalam kategori nonrepairable dikarenakan ketika komponen mengalami kerusakan, maka komponen lama diganti dengan komponen baru untuk mengantisipasi terjadinya kerusakan sistem yang lebih cepat. Confidence level yang digunakan yaitu $95 \%$ karena data yang dibutuhkan pada penelitian ini tidak seluruhnya diberikan secara rinci oleh pihak perusahaan. Tabel 10 menunjukkan hasil perhitungan kebutuhan komponen kritis pada mesin hydraulic shear dalam kurun waktu 1 tahun.

Hasil perhitungan kebutuhan komponen untuk memenuhi confidence level 95\%, maka perusahaan wajib memiliki komponen oil seal 37 unit, komponen shear blade 10 unit dan komponen oil hydraulic hose (1/2") 7 unit. Selanjutnya dihitung kuantitas barang sekali pesan dengan biaya seminimal mungkin menggunakan model EOQ, seperti ditunjukkan pada Tabel 11. 
Tabel 5. RCM information worksheet komponen oil seal

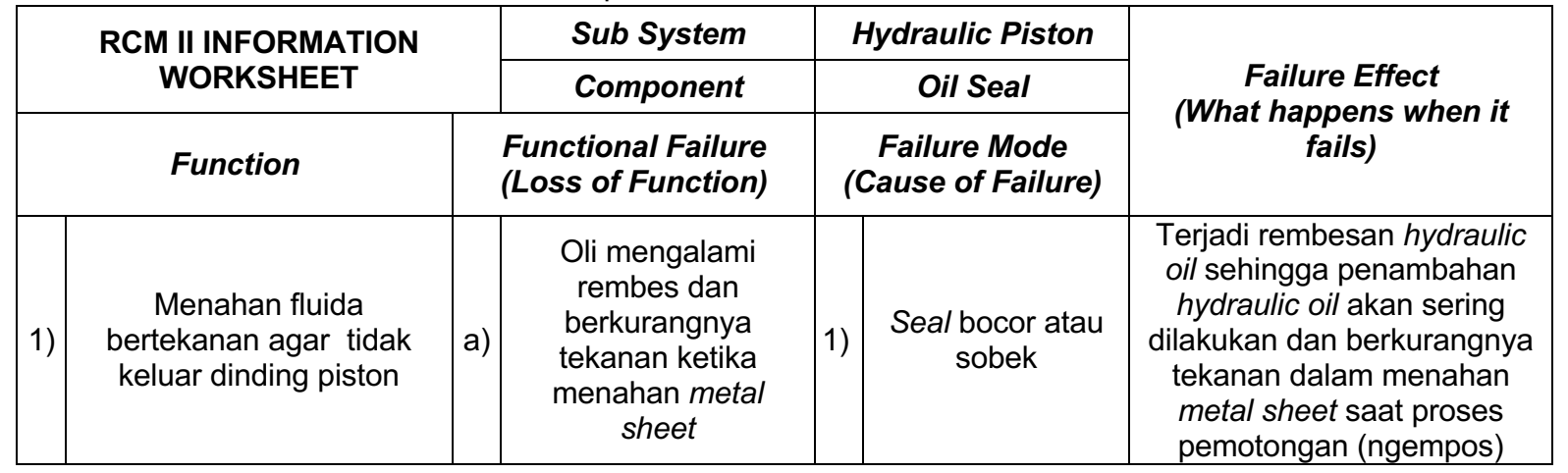

Tabel 6. RCM information worksheet komponen shear blade

\begin{tabular}{|c|c|c|c|c|c|c|}
\hline & \multirow{2}{*}{\multicolumn{2}{|c|}{$\begin{array}{l}\text { RCM II INFORMATION } \\
\text { WORKSHEET }\end{array}$}} & Sub System & & $\begin{array}{c}\text { Cutter and Blade } \\
\text { Frame }\end{array}$ & \multirow{3}{*}{$\begin{array}{c}\text { Failure Effect } \\
\text { (What happens when it } \\
\text { fails) }\end{array}$} \\
\hline & & & Component & & Shear Blade & \\
\hline \multicolumn{2}{|r|}{ Function } & & $\begin{array}{l}\text { Functional Failure } \\
\text { (Loss of Function) }\end{array}$ & & $\begin{array}{c}\text { Failure Mode } \\
\text { (Cause of Failure) }\end{array}$ & \\
\hline 1) & $\begin{array}{l}\text { Untuk memotong metal } \\
\text { sheet sesuai dengan pola } \\
\text { yang telah dibuat } \\
\text { menggunakan jig }\end{array}$ & a) & $\begin{array}{c}\text { Pemotongan tidak } \\
\text { rata }\end{array}$ & 1) & $\begin{array}{l}\text { Mata shear blade } \\
\text { tumpul dan } \\
\text { rompal }\end{array}$ & $\begin{array}{c}\text { Hasil pemotongan pada } \\
\text { metal sheet tidak rata atau } \\
\text { bergelombang }\end{array}$ \\
\hline
\end{tabular}

Tabel 7. RCM information worksheet komponen oil hydraulic hose ( 1/2")

\begin{tabular}{|c|c|c|c|c|c|c|}
\hline \multirow{2}{*}{\multicolumn{3}{|c|}{$\begin{array}{l}\text { RCM II INFORMATION } \\
\text { WORKSHEET }\end{array}$}} & Sub System & & Pipe Connection & \multirow{3}{*}{$\begin{array}{c}\text { Failure Effect } \\
\text { (What happens when it } \\
\text { fails) }\end{array}$} \\
\hline & & & Component & \multirow{2}{*}{\multicolumn{2}{|c|}{$\begin{array}{c}\text { Oil Hydraulic Hose } \\
\text { Failure Mode } \\
\text { (Cause of Failure) }\end{array}$}} & \\
\hline \multicolumn{2}{|r|}{ Function } & & $\begin{array}{l}\text { Functional Failure } \\
\text { (Loss of Function) }\end{array}$ & & & \\
\hline 1) & $\begin{array}{c}\text { Menyalurkan hydraulic oil } \\
\text { untuk menggerakan } \\
\text { hydraulic cylinder secara } \\
\text { naik turun }\end{array}$ & a) & $\begin{array}{l}\text { Hydraulic cylinder } \\
\text { tidak dapat } \\
\text { bergerak }\end{array}$ & 1) & $\begin{array}{c}\text { Pecah atau retak } \\
\text { pada bagian ujung } \\
\text { hose }\end{array}$ & $\begin{array}{c}\text { Hydraulic cylinder tidak } \\
\text { dapat bergerak yang akan } \\
\text { menyebabkan produksi } \\
\text { terhenti }\end{array}$ \\
\hline
\end{tabular}

Tabel 8. Hasil RCM decision worksheet komponen kritis

\begin{tabular}{|c|c|c|c|c|c|c|c|c|c|c|c|c|c|c|c|c|}
\hline \multicolumn{17}{|c|}{ RCM II DECISION WORKSHEET } \\
\hline \multirow{3}{*}{ Component } & \multirow{2}{*}{\multicolumn{3}{|c|}{$\begin{array}{c}\text { Information } \\
\text { Reference }\end{array}$}} & \multirow{2}{*}{\multicolumn{4}{|c|}{$\begin{array}{c}\text { Consequence } \\
\text { Evaluation }\end{array}$}} & \multirow{3}{*}{\begin{tabular}{|l|} 
H1 \\
S1 \\
O1 \\
N1 \\
\end{tabular}} & \multirow{3}{*}{$\begin{array}{l}\mathrm{H} 2 \\
\mathrm{~S} 2 \\
\mathrm{O} 2 \\
\mathrm{~N} 2\end{array}$} & \multirow{3}{*}{$\begin{array}{l}\text { H3 } \\
\text { S3 } \\
\text { O3 } \\
\text { N3 }\end{array}$} & \multirow{2}{*}{\multicolumn{3}{|c|}{$\begin{array}{l}\text { Default } \\
\text { Action }\end{array}$}} & \multirow{4}{*}{$\begin{array}{l}\text { Proposed } \\
\text { Task }\end{array}$} & \multirow{4}{*}{$\begin{array}{c}\text { Initial } \\
\text { Interval } \\
\text { (hours) }\end{array}$} & \multirow{4}{*}{$\begin{array}{l}\text { Can be } \\
\text { carried } \\
\text { out by }\end{array}$} \\
\hline & & & & & & & & & & & & & & & & \\
\hline & & & & & & & & & & & & & & & & \\
\hline & $\mathbf{F}$ & FF & FM & $\mathbf{H}$ & $\mathbf{s}$ & $\mathbf{E}$ & 0 & & & & H4 & H5 & s4 & & & \\
\hline Oil Seal & 1 & A & 1 & $\mathrm{~N}$ & $\mathrm{~N}$ & $\mathrm{~N}$ & $\mathrm{Y}$ & $\mathrm{N}$ & $\mathrm{N}$ & $\mathrm{Y}$ & - & - & - & $\begin{array}{c}\text { Schedule } \\
\text { Discard Task }\end{array}$ & 154 & $\begin{array}{c}\text { Maintenance } \\
\text { Crew }\end{array}$ \\
\hline Shear Blade & 1 & A & 1 & $\mathrm{~N}$ & $\mathrm{~N}$ & $\mathrm{~N}$ & $\mathrm{Y}$ & $\mathrm{N}$ & $\mathrm{N}$ & $\mathrm{Y}$ & - & - & - & \begin{tabular}{|c|} 
Schedule \\
Discard Task
\end{tabular} & 242 & $\begin{array}{c}\text { Maintenance } \\
\text { Crew }\end{array}$ \\
\hline $\begin{array}{l}\text { Oil Hydraulic } \\
\text { Hose (1/2") }\end{array}$ & 1 & A & 1 & $\mathrm{~N}$ & $\mathrm{~N}$ & $N$ & $\mathrm{Y}$ & $\mathrm{N}$ & $\mathrm{N}$ & $\mathrm{Y}$ & - & - & - & $\begin{array}{c}\text { Schedule } \\
\text { Discard Task }\end{array}$ & 324 & $\begin{array}{c}\text { Maintenance } \\
\text { Crew }\end{array}$ \\
\hline
\end{tabular}

Tabel 9. Hasil persentase saving cost

\begin{tabular}{|c|c|c|c|c|c|c|c|}
\hline Component & $\begin{array}{l}\text { Total Failure } \\
\text { Cost/Jam }\end{array}$ & $\begin{array}{c}\text { Total Failure } \\
\text { Cost/Period }\end{array}$ & $\begin{array}{c}\text { Total } \\
\text { Preventive } \\
\text { Cost/ Jam }\end{array}$ & $\begin{array}{c}\text { Total Preventive } \\
\text { Cost/Period }\end{array}$ & $\begin{array}{c}\text { Total Saving } \\
\text { Cost/Jam }\end{array}$ & $\begin{array}{c}\text { Total Saving } \\
\text { Cost/Period }\end{array}$ & $\begin{array}{l}\text { Percentage } \\
\text { Saving Cost }\end{array}$ \\
\hline Oil Seal & Rp. $84.268,00$ & Rp. $12.118 .878,00$ & Rp. $32.142,00$ & Rp. $2.474 .921,00$ & Rp. $52 \cdot 126,00$ & Rp. 9.653.957,00 & $61,86 \%$ \\
\hline Shear Blade & Rp. $139.188,00$ & Rp. 24.924.222,00 & Rp. $48.484,00$ & Rp. $5.866 .621,00$ & Rp. $90.703,00$ & Rp.19.057.601,00 & $65,17 \%$ \\
\hline $\begin{array}{c}\text { Oil Hydraulic } \\
\text { Hose }(1 / 2 ")\end{array}$ & Rp. $24.680,00$ & Rp. $6.180 .748,00$ & Rp. $5.773,00$ & Rp. 935.197,00 & Rp. $18.907,00$ & Rp. $5.245 .551,00$ & $76,61 \%$ \\
\hline
\end{tabular}


Tabel 10. Kebutuhan komponen kritis

\begin{tabular}{|c|c|c|}
\hline Component & Demand/year & Prob (\%) \\
\hline Oil Seal & 37 Unit & $96,40 \%$ \\
\hline Shear Blade & 10 Unit & $97,29 \%$ \\
\hline $\begin{array}{c}\text { Oil Hydraulic } \\
\text { Hose (1/2") }\end{array}$ & 7 Unit & $95,02 \%$ \\
\hline
\end{tabular}

Tabel 11. EOQ komponen kritis

\begin{tabular}{|c|c|c|}
\hline Component & $\begin{array}{c}\text { EOQ } \\
\text { (Unit) }\end{array}$ & $\begin{array}{c}\text { Frekuensi } \\
\text { Pemesanan }\end{array}$ \\
\hline Oil Seal & 19 & 2 \\
\hline Shear Blade & 2 & 5 \\
\hline Oil Hydraulic Hose (1/2") & 4 & 2 \\
\hline
\end{tabular}

EOQ memastikan perusahaan mencapai biaya pengelolaan inventory yang efisien terutama ditinjau dari ordering cost dan inventory cost. Merujuk pada Tabel 11, diperoleh jumlah optimal pemesanan dalam sekali pesan pada tiap komponen kritis yaitu 19 unit untuk komponen oil seal, 2 unit untuk komponen shear blade dan 4 unit untuk komponen oil hydraulic hose (1/2").

\section{Inventory Cost Komponen Kritis}

Inventory cost dipengaruhi oleh ordering cost, holding cost dan purchasing cost. Manajemen persediaan yang baik dapat menghindarkan perusahaan dari kelebihan maupun kekurangan inventory, sehingga perusahaan dapat meminimalisir kerugian yang dapat terjadi sewaktu-waktu. Tabel 12 menunjukkan total inventory cost yang dibutuhkan perusahaan selama 1 tahun untuk semua komponen kritis pada mesin hydraulic shear.

Tahap selanjutnya menghitung re-order point (ROP). Model ROP merupakan tingkat atau titik persediaan di mana tindakan pemesanan kembali harus diambil untuk mengisi persediaan barang atau komponen (Render \& Heizer, 2001). ROP sangat penting dalam menentukan jangka waktu pemesanan kembali pada komponen kritis. Dikarenakan barang yang dipesan tidak bisa langsung ada dan digunakan, sehingga terhindar dari kemungkinan stockout. Perhitungan ROP tidak didasari oleh distribusi kegagalan tiap komponen namun perhitungan ini menggunakan pendekatan persediaan model $\mathrm{Q}$ ekonomis. Penentuan ROP ini bergantung pada lead time pemesanan dan MTTF dari tiap komponen. Hasil perhitungan ROP dapat dilihat pada Tabel 13.

Tabel 12. Inventory cost

\begin{tabular}{|c|c|}
\hline Component & Inventory Cost \\
\hline Oil Seal & Rp. 3.109 .250 \\
\hline Shear Blade & Rp. 76.853 .500 \\
\hline Oil Hydraulic Hose (1/2") & Rp. 3.356.250 \\
\hline Total Inventory Cost & Rp. 83.318.625 \\
\hline
\end{tabular}

Tabel 13. Re-order point komponen kritis

\begin{tabular}{|c|c|}
\hline Component & Re-Order Point \\
\hline Oil Seal & 5 Unit \\
\hline Shear Blade & 1 Unit \\
\hline Oil Hydraulic Hose (1/2") & 2 Unit \\
\hline
\end{tabular}

Tabel 13 menunjukkan pemesanan kembali dilakukan jika persediaan pada masing-masing komponen kritis tersisa 5 unit untuk komponen oil seal, 1 unit untuk komponen shear blade dan 2 unit untuk komponen oil hydraulic hose $(1 / 2 ")$.

\section{Kesimpulan}

Hasil penelitian ini menyimpulkan bahwa kegiatan pemeliharaan yang sesuai dari tiap komponen kritis berdasarkan hasil RCM decision worksheet yaitu schedule discard task, dimana pada task ini melakukan penggantian komponen lama dengan komponen baru pada atau sebelum batas umur pakai sehingga dapat mengembalikan kehandalan sistem secara menyeluruh. Interval waktu penggantian optimal pada masing-masing komponen kritis yaitu 154 jam untuk komponen oil seal, 242 jam untuk komponen shear blade dan 324 jam untuk komponen oil hydraulic hose (1/2"). Berdasarkan perhitungan menggunakan metode poisson process, kebutuhan tiap komponen kritis dalam kurun satu tahun yaitu 37 unit untuk komponen oil seal, 10 unit untuk komponen shear blade dan 7 unit untuk komponen oil hydraulic hose (1/2"). Maka daripada itu, hasil penelitian ini memberikan rekomendasi kepada perusahaan sehingga pihak manajemennya dapat merencanakan dan menjadwalkan kegiatan pemeliharaan serta menentukan jumlah persediaan suku cadang tiap komponen kritis secara tepat. 


\section{Daftar Pustaka}

Ahmad, Kosasih, W. \& Wijoyo, B. (2014). Penentuan Jadwal Penggerindaan pada Mata Pahat Mesin Giling dan Penggantian Mata Gerinda dengan Menggunakan Metode Preventive Maintenance. Jurnal Kajian Teknologi, 10(2), 73-82.

Ahyari, A. (2002). Manajemen Produksi Perencanaan Sistem Produksi. Yogyakarta: BPFE UGM.

Anderson, T, W. \& Darling, D, A. (1954). A Test of Goodnees of Fit. Journal of American Statistical Association, 49(268), 765-769.

Assauri, S. (1993). Manajemen Produksi dan Operasi. Jakarta: Lembaga Penerbit Fakultas Ekonomi UI.

Corder, A. (1996). Teknik Manajemen Pemeliharaan. Jakarta: Erlangga.

Dhillon, B.S. (2002). Engineering Maintenance: A Modern Approach. New York: CRC Press LLC.

Ebeling, C. (1997). An Introduction to Reliability and Maintainability Engineering. Singapore:The McGraw-Hill Company.

Indrajit, R., \& Djokopranoto. (2003). Konsep Manajemen Supply Chain: Strategi Mengelola Manajemen Rantai Pasokan Bagi Perusahaan Modern di Indonesia. Jakarta: PT Gramedia Widiasaranan Indonesia

Moubray, J. (1991). Reliability Centered Maintenance II, Second Edition. New York: Industrial Press Inc.

Jardine, A.K. (1993). Maintenance, replacement and reliability. Canada: Pittman Publishing Company.

Kennedy, J. (2009). What Is Maintenance?. The Asset Journal, 3(1), pp. 3-11.

Kosasih, W., Ahmad \& Nurtanti, W. (2014). Pemeliharaan Terencana: Penjadwalan Interval Pembersihan Nozzle dan Penggantian Nozzle Heater pada Mesin Automatic Injection Molding E-110B (Studi Kasus: Perusahaan Guna Plast). Paper presented at $2^{\text {nd }}$ Indonesian Statistical Analysis Conference, Bandung (pp. 211214). Bandung, ID: Jurusan Teknik Industri Universitas Parahyangan.

Kurniawan, F. (2013). Manajemen Perawatan Industri Teknik dan Aplikasi. Yogyakarta: Graha IImu.
Render, B \& Heizer, J. (2001). Prinsip-prinsip Manajemen Operasi. Jakarta: Salemba Empat.

Siddiqui, A. W. \& Ben, M. (2009). Reliability Centered Maintenance in Handbook of Maintenance Management and Engineering. London: Springer.

Stamatis, D.H. (1995). Failure Mode and Effect Analysis: FMEA from Theory to Execution. Milwaukee, WI: ASQC Press.

\section{Ucapan Terima Kasih}

Pada kesempatan ini, penulis menyampaikan ucapan terima kasih kepada Lembaga Penelitian dan Pengabdian Masyarakat Universitas Tarumanagara serta semua pihak yang memberikan wawasan dan keahlian yang sangat membantu penelitian ini.

\section{Lampiran}

Tabel L1. Kriteria severity rating dari FMEA

\begin{tabular}{|c|c|c|}
\hline \multicolumn{3}{|c|}{ FMEA Severity Rating } \\
\hline Effect & Severity of Effect & Ranking \\
\hline $\begin{array}{l}\text { Hazardous } \\
\text { without } \\
\text { warning }\end{array}$ & 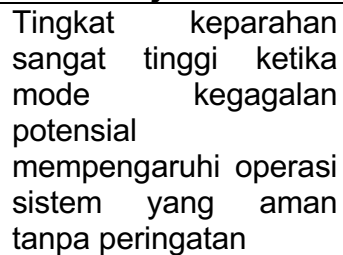 & 10 \\
\hline $\begin{array}{c}\text { Hazardous } \\
\text { with } \\
\text { warning }\end{array}$ & $\begin{array}{l}\text { Tingkat keparahan } \\
\text { sangat tinggi ketika } \\
\text { mode kegagalan } \\
\text { potensial } \\
\text { mempengaruhi operasi } \\
\text { sistem yang aman } \\
\text { dengan peringatan }\end{array}$ & 9 \\
\hline Very High & $\begin{array}{lr}\text { Sistem tidak } & \text { dapat } \\
\text { dioperasikan } & \text { dengan } \\
\text { kegagalan } & \text { yang } \\
\text { merusak } & \text { tanpa } \\
\text { membahayakan } & \\
\text { keselamatan } & \\
\end{array}$ & 8 \\
\hline High & $\begin{array}{l}\text { Sistem tidak dapat } \\
\text { dioperasikan dengan } \\
\text { kerusakan peralatan / } \\
\text { komponen }\end{array}$ & 7 \\
\hline Moderate & $\begin{array}{l}\text { Sistem tidak dapat } \\
\text { dioperasikan dengan } \\
\text { kerusakan kecil }\end{array}$ & 6 \\
\hline Low & $\begin{array}{ll}\begin{array}{l}\text { Sistem tidak } \\
\text { dioperasikan } \\
\text { kerusakan }\end{array} & \begin{array}{l}\text { dapat } \\
\text { tanpa }\end{array} \\
\end{array}$ & 5 \\
\hline Very Low & $\begin{array}{lr}\text { Sistem } & \text { dapat } \\
\text { dioperasikan } & \text { dengan } \\
\text { penurunan } & \text { kinerja } \\
\text { yang signifikan } & \\
\end{array}$ & 4 \\
\hline Minor & $\begin{array}{l}\text { Sistem } \\
\text { dioperasikan dengat } \\
\text { beberapa penurunan } \\
\text { kineria }\end{array}$ & 3 \\
\hline
\end{tabular}




\begin{tabular}{|c|l|c|}
\hline \multicolumn{3}{|c|}{ FMEA Severity Rating } \\
\hline Effect & \multicolumn{1}{|c|}{ Severity of Effect } & Ranking \\
\hline Very Minor & $\begin{array}{l}\text { Sistem dapat } \\
\text { dioperasikan dengan } \\
\text { gangguan minimal }\end{array}$ & 2 \\
\hline None & Tidak berpengaruh & 1 \\
\hline
\end{tabular}

Tabel L2. Kriteria occurance rating dari FMEA

\begin{tabular}{|c|c|c|}
\hline \multicolumn{3}{|c|}{ FMEA Occurance Rating } \\
\hline $\begin{array}{c}\text { Probability } \\
\text { of Failure }\end{array}$ & Failure Prob. & Ranking \\
\hline $\begin{array}{c}\text { Very High: } \\
\text { Failure is } \\
\text { almost } \\
\text { inevitable }\end{array}$ & $>1$ in 2 & 10 \\
\cline { 2 - 3 } & 1 in 3 & 9 \\
\hline $\begin{array}{c}\text { High: } \\
\text { Repeated } \\
\text { failures }\end{array}$ & 1 in 8 & 8 \\
\cline { 2 - 3 } $\begin{array}{c}\text { Moderate: } \\
\text { Occasional } \\
\text { failures }\end{array}$ & 1 in 20 & 7 \\
\cline { 2 - 3 } & 1 in 80 & 6 \\
\hline $\begin{array}{c}\text { Low: } \\
\text { Relatively } \\
\text { few failures }\end{array}$ & 1 in 2.000 & 5 \\
\cline { 2 - 3 } $\begin{array}{c}\text { Remote: } \\
\text { Failure is } \\
\text { unlikely }\end{array}$ & 1 in 150.000 & 2 \\
\hline \multicolumn{2}{|c|}{ in 1.000 .000} & 1 \\
\hline
\end{tabular}

Tabel L3. Kriteria detection rating dari FMEA

\begin{tabular}{|c|l|c|}
\hline \multicolumn{3}{|c|}{ FMEA Detection Rating } \\
\hline Detection & $\begin{array}{l}\text { Likelihood of Detection } \\
\text { by Design Control }\end{array}$ & Ranking \\
\hline $\begin{array}{c}\text { Cannot } \\
\text { Detect }\end{array}$ & $\begin{array}{l}\text { Pengendalian desain } \\
\text { tidak dapat mendeteksi } \\
\text { potensi penyebab / } \\
\text { mekanisme dan mode } \\
\text { kegagalan selanjutnya }\end{array}$ & 10 \\
\hline Very & $\begin{array}{l}\text { Sangat kecil } \\
\text { kemungkinan kendali } \\
\text { desain akan mendeteksi } \\
\text { sebab / mekanisme } \\
\text { potensial dan mode } \\
\text { kegagalan berikutnya }\end{array}$ & \\
\hline Remote & $\begin{array}{l}\text { Kesempatan jarak jauh } \\
\text { kendali desain akan }\end{array}$ & 8 \\
\hline
\end{tabular}

\begin{tabular}{|c|c|c|}
\hline \multicolumn{3}{|c|}{ FMEA Detection Rating } \\
\hline Detection & $\begin{array}{l}\text { Likelihood of Detection } \\
\text { by Design Control }\end{array}$ & Ranking \\
\hline & 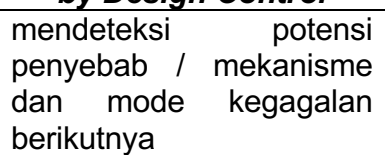 & \\
\hline Very Low & $\begin{array}{lr}\text { Sangat } & \text { kecil } \\
\text { kemungkinan kendali } \\
\text { desain akan mendeteksi } \\
\text { sebab / mekanisme } \\
\text { potensial dan mode } \\
\text { kegagalan selanjutnya }\end{array}$ & 7 \\
\hline Low & $\begin{array}{l}\text { Kemungkinan kecil } \\
\text { kendali desain akan } \\
\text { mendeteksi sebab / } \\
\text { mekanisme potensial dan } \\
\text { mode kegagalan } \\
\text { berikutnya }\end{array}$ & 6 \\
\hline Moderate & $\begin{array}{l}\text { Kemungkinan sedang } \\
\text { kendali desain akan } \\
\text { mendeteksi sebab / } \\
\text { mekanisme potensial dan } \\
\text { mode kegagalan } \\
\text { berikutnya }\end{array}$ & 5 \\
\hline $\begin{array}{c}\text { Moderatel } \\
\text { y High }\end{array}$ & $\begin{array}{l}\text { Peluang cukup tinggi } \\
\text { kendali desain akan } \\
\text { mendeteksi } \\
\text { penyebab / mekanisme } \\
\text { dan mode } \\
\text { berikutnya }\end{array}$ & 4 \\
\hline High & $\begin{array}{l}\text { Kemungkinan besar } \\
\text { kendali desain akan } \\
\text { mendeteksi sebab / } \\
\text { mekanisme potensial dan } \\
\text { mode kegagalan } \\
\text { berikutnya }\end{array}$ & 3 \\
\hline Very High & $\begin{array}{l}\text { Peluang yang sangat } \\
\text { tinggi dari kendali desain } \\
\text { akan mendeteksi sebab / } \\
\text { mekanisme potensial dan } \\
\text { mode kegagalan } \\
\text { berikutnya }\end{array}$ & 2 \\
\hline $\begin{array}{l}\text { Almost } \\
\text { Certain }\end{array}$ & $\begin{array}{l}\text { Pengendalian desain } \\
\text { akan mendeteksi potensi } \\
\text { penyebab / mekanisme } \\
\text { dan mode kegagalan } \\
\text { selanjutnya }\end{array}$ & 1 \\
\hline
\end{tabular}


DOI: https://doi.org/10.26593/jrsi.v9i3.4023.153-162

Halaman ini sengaja dikosongkan.

This page is intentionally left blank. 